\title{
Togo Mizrahi, Agent of Exchange
}

\section{PREVIEW}

We hear a band strike up festive music. We see street vendors selling their wares from carts lining a city street. A man and boy, holding hands, walk past the vendors. As they recede into a distant crowd, a pair of young men, both in Western suits and tarbooshes, stroll into and out of the frame. Two riders-one in a dark galabiya and tarboosh, the other in a light galabiya and turban-swing a gondola high into the air, cutting an arc across the screen. Young children circle by, riding on a carousel. Men push a manually operated fun wheel, as car after car filled with children rise and disappear out of the frame. A vendor tips a large, ornate brass carafe, and a translucent liquid pours out of the long spout in a wide curve, filling a glass. In a park, girls in light-colored dresses play chase. A pair of men in overcoats and tarbooshes walk along a path, followed by a group of boys who pause to peer at the camera (fig. 1). In the background, to the left, a woman in black wearing a face veil also looks in the direction of the camera. Behind them to the right, a man in a white galabiya and turban sits on the grass, deep in conversation. At the beach, a family walks along the shore-the distinctive seaside cabins and corniche of Alexandria visible to the right of the frame. People clustered in small groups picnic on the sand. The skirt hems of women dressed in the latest European fashion flap in the sea breeze along with the awnings of beach umbrellas.

This kinetic, carnivalesque montage appears in a 1937 Egyptian feature film, Al-'Izz bahdala (Mistreated by Affluence). ${ }^{1}$ A title screen identifies the celebration as "Shamm al-nasim, 'id al-sha'b" - that is, "Shamm al-nasim, the people's feast." Shamm al-nasim ("Smelling the Breeze") - is a spring festival that shares some characteristics with other seasonal celebrations in the region, like Nowruz. Shamm al-nasim is also a uniquely Egyptian festival, with roots in ancient Egyptian practices. Egyptians take to the streets, parks, beaches, and green spaces. 


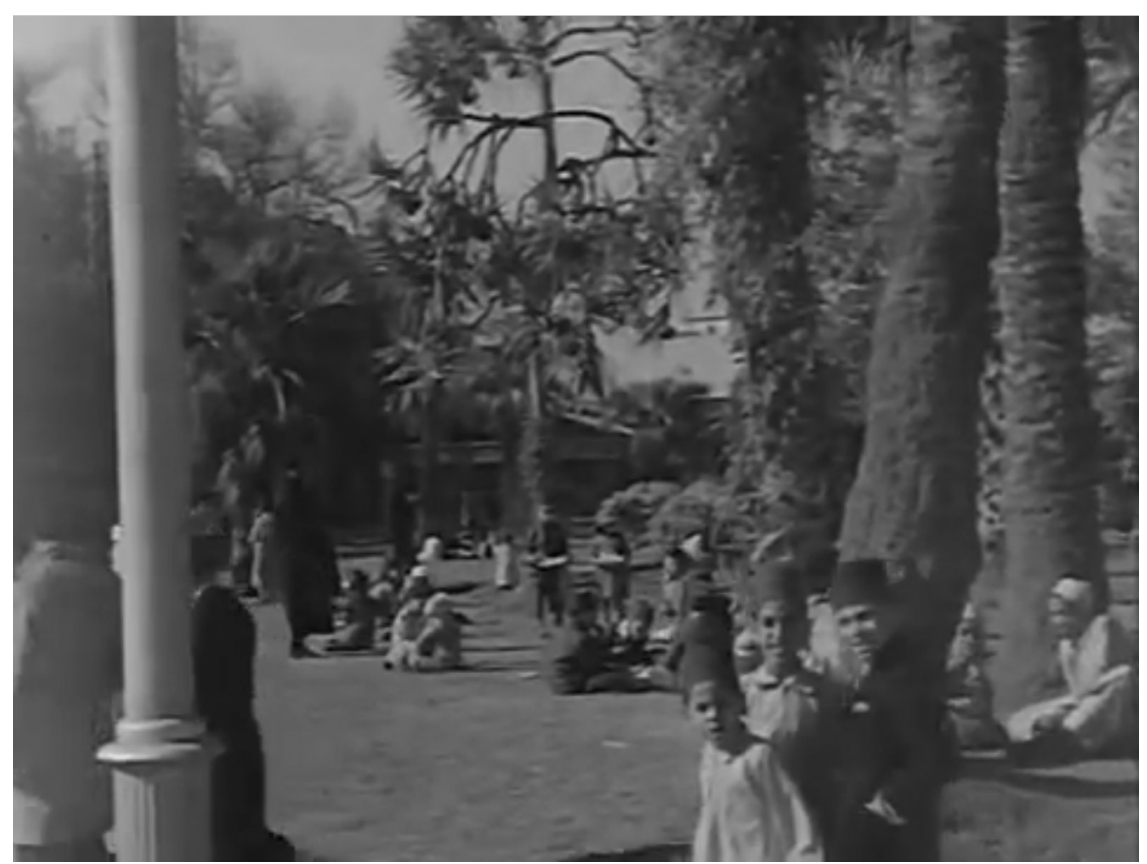

FIGURE 1. Alexandria residents relaxing in a park. Screenshot from Mistreated by Affluence (Togo Mizrahi, 1937).

The footage shows what appear to be Alexandria residents engaging in leisure activities in identifiable locales. None of the credited actors appear in the montage. Children display curiosity about the camera. The viewer is invited to read these images as authentic-even as we recognize the constructedness of the montage. Social codes of dress give the viewer cues to categorizing the individuals included in the footage. Members of the rising middle class-the effendiyya-are shown seeking entertainment and diversion alongside members of the popular classes. ${ }^{2}$ This carefully edited montage constructs a festival day in which Alexandrians across the socioeconomic spectrum celebrate in public spaces together.

While the celebration of Shamm al-nasim is pegged to the Coptic calendar, falling on the day after Easter, in modern times it has historically been celebrated by Muslim, Christian, and Jewish Egyptians alike. The narrative scenes that bracket the montage highlight this intercommunal aspect of the festival. In the scene preceding the montage, two families-one Muslim and one Jewish-prepare together for the next day's feast. As the two mothers and their adult daughters package up the traditional Egyptian dishes they prepared for the picnic, the daughters' fiancés deliver their contribution: fisikh, salted fish consumed on the holiday. In the scene that follows the montage, the two families picnic on the beach-literally breaking bread together. Read in tandem, the montage and the narrative scenes portray Shamm al-nasim as a universal practice of all Egyptians regardless of class or religion. 
Mistreated by Affluence was written, directed, and produced by Togo Mizrahi, a Jewish native of Alexandria, and it stars a Jewish actor who performed under the screen name Chalom. Shamm al-nasim holds great appeal for Mizrahi; scenes from the festival feature prominently in three of his films, including Mistreated by Affluence. ${ }^{3}$ The holiday is both distinctly Egyptian, and universally celebrated in Egypt. The communal celebration of the festival enacts a pluralist vision of the Egyptian polity that Mizrahi projects in his films.

Another scene in Mistreated by Affluence also explores the intersection between coexistence and class. The protagonists_Chalom, a Jew; and Abdu, a Muslimstart out impoverished and rapidly climb the socioeconomic ladder together, only to return to their modest circumstances after a fall. At the start of the film 'Abdu is employed as a butcher's assistant, and Chalom is an itinerant lottery-ticket seller. When the butcher dies, 'Abdu unexpectedly inherits the shop. With this windfall, 'Abdu rents the empty storefront next door for his friend. Chalom hangs a bilingual sign (Arabic and French) on his new shop. In Arabic, the sign reads "Chalom, for the sale and redemption of lottery tickets." During the course of the film, the arabophone Chalom demonstrates at least a passing knowledge of Italian and Greek, but he does not speak French. So, when writing his sign, Chalom adopts an accessible model-the common signs for currency exchange in the port city. In contrast to the idiomatic French that appears alongside Arabic in the credits and intertitles of the film, the broken French in Chalom's handwritten scrawl is difficult to decipher, reading as either "Chalom Agen d'echange" or "Chalom, Agen de Change"-Chalom, agent of exchange. ${ }^{4}$

Like many of Mizrahi's other popular comedies and musical melodramas of the 1930 and 1940s, Mistreated by Affluence features a convoluted plot of masquerade, role-play, and mistaken identity. In the film, Chalom exchanges identities as well as lottery tickets. As an "agent of exchange," Chalom acts in ways that also set into motion the changes other characters undergo in the film. Plotted in this way, the film's coexistence narrative serves to expose the nation's "masquerade of unity." The notion of exchange-from cultural exchange to exchange of identities-is a key element in Mizrahi's films. Togo Mizrahi and the Making of Egyptian Cinema teases out the relationship between the notion of exchange and pluralist nationalism in Mizrahi's oeuvre.

The storefront also is the site of an assertion of identity. In an earlier scene in Mistreated by Affluence, the camera pans by the vacant storefront next to the butcher shop where 'Abdu is employed. Posters advertising Mizrahi's 1933 film, Awlad Misr (Children of Egypt) plaster the closed grate of the empty shop. ${ }^{6}$ In the context of the coexistence narrative, the inclusion of the ad functions as a willful assertion of identity. The signs read "Togo Mizrahi presents Children of Egypt" but the word "presents" is written in such small letters in both Arabic and French that it is barely visible. So, in the brief moment when the sign is visible, what catches the eye is "Togo Mizrahi" and "Children of Egypt." Mizrahi, the Jewish director, wishes to identify himself, along with the Jewish character, Chalom-whose sign 


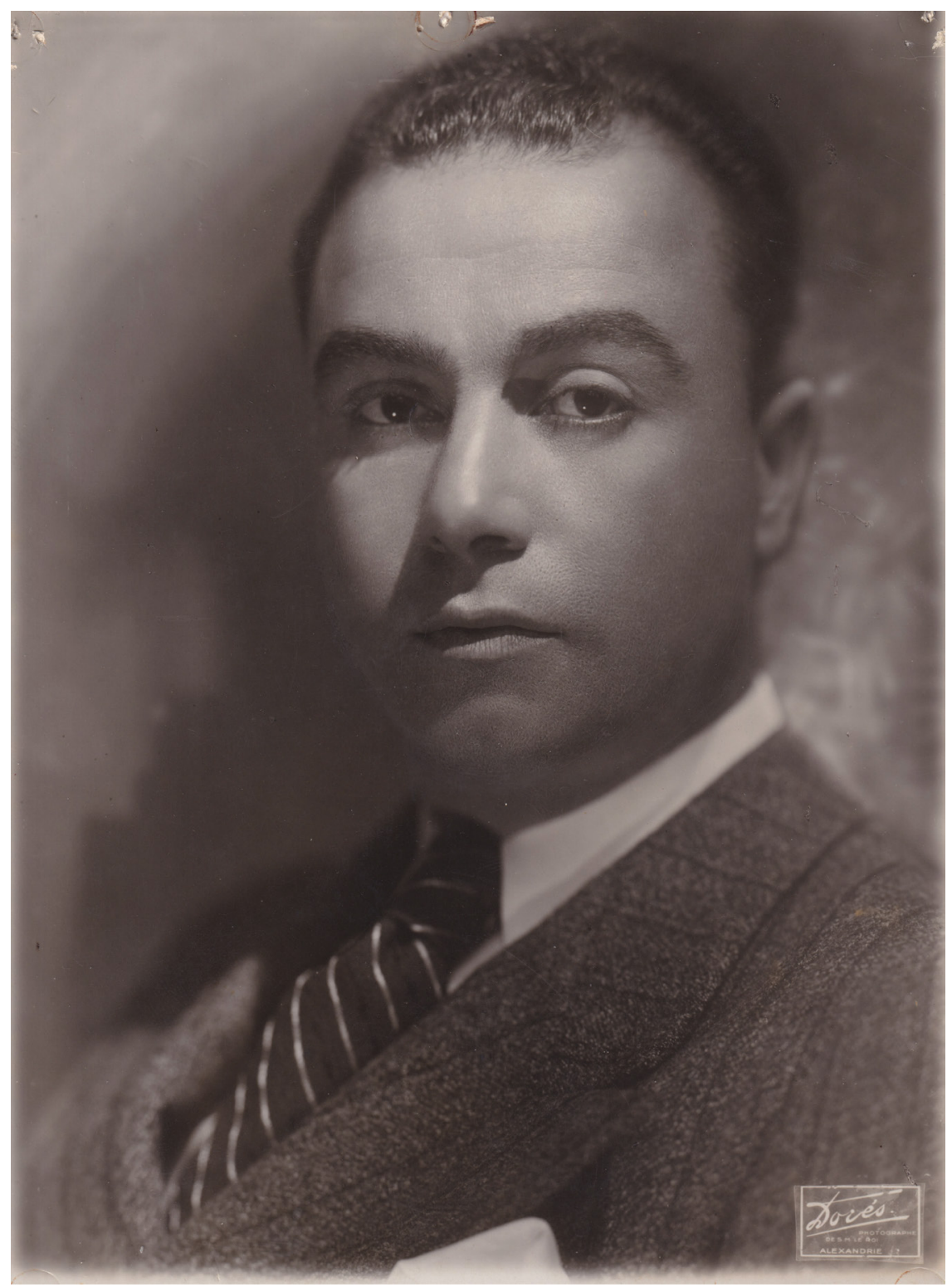

FIGURE 2. Portrait of Togo Mizrahi by Studio Umberto Dorés. Courtesy of Jacques Mizart.

later graces the same shop-as children of Egypt. This book examines the place of Togo Mizrahi, "child of Egypt," in Egyptian cinema history.

Togo Mizrahi was one of the most prolific filmmakers of his day; over the course of his productive sixteen-year career in the Egyptian film industry-from 1930 to 1946 - he directed and produced thirty Arabic-language feature films, 
most of which he also wrote. In addition to his contributions to Egyptian cinema in Arabic, in his Egyptian studio he also produced four Greek-language films between 1937 and 1943 (fig. 2).

The development of a local cinema industry was a source of national pride for Egyptian filmmakers, critics, and audiences alike in the midst of the anticolonial struggle. Mizrahi saw himself as engaged in this collective effort; and his contemporaries heralded his contributions to building a national film industry.

But Mizrahi, like many other Jews who lived in Egypt, never held Egyptian nationality. How did it come about that Mizrahi did not hold Egyptian nationality, even though his family could trace roots in Egypt back several generations?7 And how did an individual who did not hold Egyptian nationality come to identify with the Egyptian national struggle? In the section that follows I begin to address these questions by exploring the complex relationships between language, identity, and nationality among Jews in Egypt.

Contemporaneous critics and cinema historians alike have often resorted to ascertaining the nationality of filmmakers and actors as an index for determining whether or not to consider a film as "Egyptian." By this measure, the films written, directed, and produced by Togo Mizrahi-a native of Alexandria who held Italian nationality-would not qualify as Egyptian films. For both historical and theoretical reasons, nationality is a problematic criterion for determining the contours of national cinema-itself a problematic term. In the section below titled "National Cinema without Nationality," I review institutions that shaped the development of the Egyptian film industry in the 1920 s and 1930 s as an alternative model for defining the boundaries of Egyptian national cinema. Then, I articulate ways cinema was viewed during that period as part of a nationalist project, differentiating between national cinema, patriotic industry boosterism, and nationalist cinema. In the concluding section of this chapter, I introduce Togo Mizrahi as a case study for exploring this alternative model of Egyptian national cinema.

\section{EGYPTIAN JEWS: BETWEEN NATIONALITY \\ AND NATIONALISMS}

In the mid-nineteenth century, the population of Jews in Egypt numbered approximately five thousand. ${ }^{8}$ At its height in the 1930 s and 1940s, the Jewish population grew to between seventy-five and eighty thousand. ${ }^{9}$ Following the 1948 ArabIsraeli war, approximately twenty thousand Jews left Egypt-Mizrahi among them..$^{10}$ In the aftermath of the 1956 Suez War, the Egyptian Jewish community was reduced to between five and fifteen thousand people. ${ }^{11}$ At present, only a handful of Jews remain in Egypt.

Discussions of the Egyptian Jewish experience tend to focus either on the achievements of Jews at the peak of this arc, or on a narrative of decline. Proponents of the former tendency draw attention to indices of Jewish successes-economic, political, cultural, and artistic. But such celebrations of an era of coexistence 
frequently slide into uncritical nostalgia. ${ }^{12}$ By contrast, some historians and members of the Egyptian Jewish diaspora adopt what Marc Cohen has termed a "neo-lachrymose" narrative, which traces an unbroken line of Jewish persecution under Islamic rule from the rise of Islam to the present. ${ }^{13}$

The story of Mizrahi's success and the abrupt end to his career could provide evidence to proponents of both views. But Mizrahi's narrative also opens up an array of nuanced, qualitative questions about the nature of Egyptian Jewish identity and the participation of Jews in Egyptian society. Exploring the films of Togo Mizrahi-a noncitizen who identified as an Egyptian nationalist-provides a means to explore the complicated relationships between identity, nationality, and politics among Jews in Egypt.

\section{Jewish Nationalities in Egypt}

Egyptian Jews were linguistically and culturally heterogeneous. Late-nineteenthcentury economic growth in Egypt spurred Jewish immigration from around the Mediterranean, particularly from other parts of the Ottoman Empire. ${ }^{14}$ The Jewish community that predated the influx of immigrants in the nineteenth century spoke Egyptian Arabic. ${ }^{15}$ Immigrants from the Maghreb (North Africa) and the Mashriq (Arab East) spoke a variety of Judeo-Arabic dialects. Sephardi Jews who immigrated from Turkey and Greece spoke Ladino, as well as Turkish or Greek. Some Italian Jews spoke Italian, although not all Jews who claimed or held Italian nationality actually hailed from Italy or spoke Italian. ${ }^{16} \mathrm{~A}$ small community of Ashkenazi immigrants who settled in Egypt spoke Yiddish. ${ }^{17}$

Through the late nineteenth century, Italian was the official language of the Jewish community in Alexandria. By the early twentieth century, French had become the preferred language of the emerging Levantine bourgeoisie in Egypt, including the Jews. ${ }^{18}$ Arabic was looked down upon by francophone Egyptian Jews, who associated the language with the poor residents of Cairo's medieval Jewish quarter, Harat al-yahud. ${ }^{19}$ Mizrahi, whose family was counted among the Alexandrian cosmopolitan elites, spoke Italian at home and was educated in French schools in Alexandria. However, not only do Mizrahi's films demonstrate his affection for Egyptian colloquial Arabic; they also challenged the Egyptian Jewish bourgeoisie to reconsider their relationship to Arabic and to related notions of Egyptianness. ${ }^{20}$

Jews in Egypt also held a wide array of nationalities. There was often little relationship between a family's place of origin and its nationality. Jacqueline Shohet Kahanoff and André Aciman-two Jewish writers who grew up as noncitizen residents of Egypt-both memorably relate how they were confronted with the disconnect between their self-identification and their nationality. Kahanoff, whose father immigrated to Egypt from Iraq, and whose mother was the daughter of immigrants from Tunisia, did not know how to respond when, as a child, strangers on the beach inquired about her identity. "I knew I was not Egyptian," she writes. "[T]hinking of my grandparents, I replied that I was Jewish and Persian, believing 
that Baghdad, the city they came from, was the country from which all beautiful rugs came." ${ }^{21}$ Raised and educated in francophone environs, André Aciman, who as a child aspired to become a diplomat, assumed he was French. His uncle indelicately informed Aciman that he held Italian nationality but that his family was not from Italy; rather, they had immigrated to Egypt from Turkey. ${ }^{22}$

The disorientation Kahanoff and Aciman articulate is, in part, an outgrowth of their families' emigration to Egypt a generation or two earlier. But migration is only one of the factors that contributed to a particularly complex and unstable construction of nationality in Egypt. Under the Capitulations-a series of treaties between the Ottoman Empire and the European powers-foreign consulates were permitted to grant nationality and protégé status to local residents. Foreign nationality was made particularly desirable by the special privileges granted by the Capitulations to bearers of European nationality. As a result of these factors, an individual's nationality might bear little relationship either to external markers of group identity - such as language-or to his or her self-identification. ${ }^{23}$

The notion of nationality-and its legal codification in terms of citizenshipemerged in the late nineteenth and early twentieth centuries. ${ }^{24}$ Egyptian nationality was codified in 1929 with the promulgation of the Egyptian Nationality Law. Building on the precedent of a series of administrative decrees starting in 1892, when Egypt was still nominally a province of the Ottoman Empire, the Egyptian Nationality Law, passed in 1929, extended rights of citizenship to those who had been established in Egypt prior to 1848. This law, however, did not lead to a stable, consistent legal definition of nationality, since these rights were not universally extended to all eligible. Egyptian Jews, in particular, were denied nationality in significant numbers. By the late 1940s, approximately forty thousand Jews who, according to the terms of the law, should have been granted Egyptian nationality were registered as stateless. ${ }^{25}$

Sarah Abrevaya Stein employs the term "extraterritorial Jews" to describe the Jewish migrants within the Ottoman and former Ottoman sphere, as well as Jewish protégés of European powers. ${ }^{26}$ In the early twentieth century, the notion of nationality was very much in flux and being defined variously by courts, consular officials, customs agents, and other civil authorities, as Stein and Will Hanley demonstrate. ${ }^{27}$ Following Stein and Hanley, I approach nationality in interwar Egypt as a negotiated and contingent status, not a fixed identity.

\section{Jews and Egyptian Nationalism}

In this book I contend that Mizrahi's oeuvre should be viewed within the context of the nationalist sentiment prevalent in the Egyptian film industry of his time. Throughout his career, Mizrahi produced commercial comedies and popular musical melodramas. Nevertheless, Mizrahi used his films as a platform for addressing social issues, from income disparity to the changing roles of women in Egyptian society. Mizrahi's films also projected a distinctly inclusive national 
imaginary. Less than two decades before the dispersion of the Egyptian Jewish community, Mizrahi produced films - some featuring Jewish actors Layla Murad and Leon Angel (Chalom) - that articulated a pluralist Egyptian nationalism.

Togo Mizrahi was not the only Egyptian Jew to articulate his commitment to Egyptian nationalist causes. Jewish involvement in Egyptian politics from the late nineteenth century through the 1940s varied widely, both in level of commitment and in political opinion. Jews were to be found in the royal court, on the rolls of the independence-minded Wafd Party, and in Communist organizations. ${ }^{28}$ Members of the Jewish bourgeoisie and elites tended to be motivated by the desire to protect their business interests. ${ }^{29}$

Even among Jews who identified as Egyptian nationalists, one can find a range of inflections and political commitments. In the late nineteenth century, journalist and playwright Ya'qub Sannu' embraced an anticolonial Egyptian nationalism in his popular journal of political satire, Abu nazzara zarqa..$^{30}$ In the interwar period, the Qattawi family produced two leaders of the Sephardi community of Cairo. Yusuf Aslan Qattawi Pasha, who led the community from 1924 to 1942, was a supporter of the monarchy who served in parliament and in a number of government posts. ${ }^{31} \mathrm{He}$ embraced a "socially conservative and business oriented" form of nationalism. ${ }^{32}$

His son, René Qattawi, led the Cairo Sephardi community from 1943 to 1946. Togo Mizrahi and René Qattawi were contemporaries, and both appear to have been influenced by the spirit of the 1919 Revolution. When Egyptians rose up against British colonial rule in 1919, their demands for national self-determination were inflected with a pluralist vision of the nation they aimed to liberate. In 1935, René Qattawi established the Association of Egyptian Jewish Youth to promote Jewish linguistic, cultural, and social integration in Egypt under the slogan "Egypt is our homeland, Arabic is our language." 33

In his capacity as leader of the Sephardi community of Cairo, René Qattawi "aggressively opposed political Zionism." ${ }^{4}$ There were few active Zionist youth movements in Egypt and, prior to 1948, few Jews who left Egypt to settle in Palestine as a fulfillment of Zionist ideology. But, unlike René Qattawi, some saw no conflict between identifying as an Egyptian patriot and supporting Zionist efforts in Palestine. Some elite Egyptian Jewish families who supported the Egyptian national struggle also sent donations to aid Jewish settlement in Palestine. ${ }^{35}$

The prolific writings of essayist and poet Murad Farag reflect the seamless integration of two nationalist affiliations that from a later perspective seem utterly irreconcilable. Farag, a Karaite Jew, wrote about the histories and cultural affinities shared by Arabic-speaking Jews and Muslims. Farag contributed nationalist essays to the influential journal Al-Jarida, edited by Lutfi al-Sayyid. ${ }^{6} \mathrm{He}$ also published a volume of poetry on Jewish themes with Zionist overtones, Al-Qudsiyyat (Sacred/ 
Jerusalemite Topics, 1923). According to Sasson Somekh, Farag's Zionist poems reflect his desire to "persuade follow Egyptians that Jewish national aspirations are just and in keeping with Egyptian nationalism." ${ }^{37}$

\section{Egyptian Jews, between Conflicting Nationalisms}

Although the political commitments or lack thereof varied among Egyptian Jews, their fates were uniformly determined by the rise of parochial-nationalist ideologies in the first half of the twentieth century. Few Egyptian Jews identified as Zionists; but the establishment of the state of Israel ultimately contributed to the dissolution of the Egyptian Jewish community. In Egypt during the interwar period, new "supra-Egyptian" nationalist movements emerged, including the Pan-Islamic movement the Muslim Brotherhood, founded in 1928, and the ultranationalist Misr al-fatat (Young Egypt), established in 1933. Although these emerging strains of nationalism shared an anticolonial agenda, the supranationalists drew inspiration from Arab-Islamic sources and articulated their political agenda in terms shared by other Arabs and Muslims. The ascendant nationalist strains that privileged religious and ethnonational identity increasingly excluded resident non-Muslim minorities. ${ }^{38}$

The arc of Mizrahi's career maps shifting notions of the Egyptian polity and its relationship to Egyptian cinema. By the 1940s noncitizen residents of Egypt-like Mizrahi-were increasingly marginalized. In 1946 Mizrahi wrapped production on what was to be his final film. Within a few years, Mizrahi, like a significant percentage of the Egyptian Jewish community, had left Egypt.

In his day, Mizrahi was viewed by his peers and by contemporaneous critics as a consummate professional who contributed to the drive to establish a cinema industry in Egypt. But later film critics and historians who embraced the socialist-inflected, pan-Arab, and anticolonial nationalism espoused by Gamal Abdel Nasser did not share this view. From their perspective, Mizrahi had three strikes against him: he was a capitalist; he was a foreigner; and he was a Jew accused of Zionist sympathies. ${ }^{39}$

These terms continue to shape how Mizrahi is remembered in Egypt today. In recent years, there has been a resurgence of interest in Egypt's cosmopolitan past, including the Egyptian Jewish community..$^{\circ}$ There is also a concomitant revival of interest in Mizrahi and his films. But many of these efforts are distorted by the polemics of the Arab-Israeli conflict. The headline of a 2005 retrospective of Mizrahi's career, for example, poses the question of whether he was "a cinema director from Egypt, or a booby-trapped Jewish bomb?" ${ }^{11}$ This rhetoric obscures Jewish involvement in a project-Egyptian cinema-that was, in its time, deemed a contribution to the country's struggle for independence. This book aims to recuperate the narrative of Togo Mizrahi as an Egyptian filmmaker by disrupting dominant notions of what constitutes Egyptian national cinema. 


\section{WHAT IS EGYPTIAN CINEMA?}

A study of early Egyptian cinema production and criticism provides insights into the evolving and contested nature of Egyptian national identity in the 1930s and 1940s. The question "What makes a movie Egyptian?" is closely bound up with the question "Who is Egyptian?" Togo Mizrahi did not hold Egyptian nationality, but did he make Egyptian movies? Both contemporaneous critics and film historians scrutinize the identities of participants-behind and in front of the camera-to determine a film's Egyptian bona fides. An unresolved dispute over which film deserves the title "first Egyptian film" exemplifies this practice. Should it be Fi bilad Tut 'Ankh Amun (In the Land of Tutankhamun, Victor Rosito, 1923) or Layla (Vedat Örfi and Stefan Rosti, 1927)? I present the contours of the debate to analyze the underlying assumptions about the criteria critics use to determine what makes a film "Egyptian."42

\section{In the Land of Tutankhamun (1923)}

King Tut's tomb was discovered in 1922 during a dig led by British archaeologist Howard Carter. The following year, on 11 July 1923, a film set during the famous expedition, In the Land of Tutankhamun, premiered in Cairo. Contemporaneous reports about the film indicate that it was a hybrid of genres: a fictional film set in modern Egypt that also documented "the labor involved in opening the tomb of Tutankhamun." ${ }^{43}$ The film was directed by Victor Rosito, a Cairo-based lawyer, who, like Mizrahi, lived in Egypt but held Italian citizenship. Rosito is quoted as saying that he was motivated to write, produce, and direct the film in order to "present a good image of [Egypt] abroad." 44 In the Land of Tutankhamun featured five actors: three Italian nationals and two Egyptians, including the popular stage actor Fawzi Munib, who, at the time, led a theater troupe together with his wife, Mary Munib. ${ }^{45}$ Alexandria resident Muhammad Bayumi, an Egyptian, operated the camera. Bayumi had studied filmmaking in Europe and went on to direct several films, found a cinema school in Alexandria, and play an important role in establishing the Egyptian film industry. ${ }^{46}$

Contemporaneous sources were split over whether or not to celebrate In the Land of Tutankhamun as an Egyptian film. In its coverage of the premiere, the daily al-Ahram enthusiastically endorsed the film: "We believe that the distribution of this film in foreign countries would return enormous benefit to Egypt and to Egyptians because it shows them as they really are, not how they appear in some exhibitions in Europe and America." ${ }^{47}$ The article implies that In the Land of Tutankhamun offsets the prevalent Orientalist cinematic gaze of foreign filmmakers-evident in actualities, documentaries, and feature films like The Sheik (George Melford, 1921). In doing so, in the al-Ahram critic's view, the film serves an important public-relations function abroad.

By contrast, a critic in the cinema journal Al-Suwar al-mutaharika is more circumspect, identifying In the Land of Tutankhamun as the first feature film "about 
Egypt." While the article thanks Victor Rosito for his "individual efforts," and for his respectful treatment of Egyptian culture, the director's nationality prevents the critic from embracing the film as "Egyptian." 48

Later critics continue to debate what constitutes Egyptian cinema and when it began. In his 1989 survey of early Egyptian cinema, Ahmad al-Hadari pronounces In the Land of Tutankhamun the first Egyptian feature film. Al-Hadari minces no words articulating the importance of this film in the development of Egyptian cinema: "We have before us the first Egyptian feature film.." ${ }^{49}$ In al-Hadari's view, since the film was shot in Egypt, with modern Egypt as its subject, and since the production involved Egyptians both on-screen and behind the camera, the film should be considered Egyptian. One historian remarks, "[W]hatever misgivings one might have about his views, at the heart of al-Hadari's argument is a celebration of the multinational nature of Egyptian society." ${ }^{\circ}$

Before al-Hadari published his seminal chronicle of early cinema in Egypt, there was some uncertainty among historians about the length of Rosito's film, and whether it should be considered a feature or a documentary. ${ }^{51}$ But since 1989 , any scholar or critic wishing to enter the debate needed to contend with al-Hadari's evidence. Di'ya Mar'i reevaluates al-Hadari's sources, drawing the opposite conclusion about the national character of the film. Taking a narrow view of who is Egyptian, Mar'i characterizes early cinema in Egypt as a near monopoly controlled by foreigners - from production to distribution to cinema ownership. For Mar'i, In the Land of Tutankhamun represents "the first breakthrough in the foreign monopoly on cinema production by the pioneering Muhammad Bayumi, who was the first Egyptian to stand behind the camera." ${ }_{52}$ However, the nationality of the director, Victor Rosito, along with some of his comments, which in Mar'i's view reflect a folkloric representation of Egypt typical of European Orientalist views, disqualify the film from consideration. ${ }^{53}$

\section{Layla (1927)}

Popular consensus holds that Layla, released in 1927, was the first Egyptian fulllength feature film. As Kay Dickinson asserts, "From the very outset, Layla was never going to be received as 'just a film'; it was destined to take on a more iconic status." ${ }^{44}$ Layla's mythic appeal is evident. The film was spearheaded and financed by a famed stage actress, 'Aziza Amir, and featured a slate of local talent on-screen. In its announcement about the upcoming premier, al-Ahram proclaims, "Appearing in the Egyptian atmosphere are bright, shining stars wishing to serve Egypt and its people, wishing to create wonderful propaganda for Egypt and its peoplea propaganda that will provide the greatest service to Egypt and its people. This is cinema-pure, Egyptian national cinema." ${ }_{55}$ Referring to Layla as "a fetish of Egyptian achievement," Dickinson notes, "The lion's share of critical and historical accounts of the film and its creator are ... saturated with figural speech and nationalist fervor in both their descriptions and appreciation of the movie." 56 
Within a few years, the mythology surrounding Layla had firmly taken root. In a survey of the state of domestic film production published in early 1934, Gama'a al-nuqqad al-sinima'iyyin (the Group of Cinema Critics [G.C.C.]) identifies Layla as the first truly Egyptian feature film, despite the fact that Muhammad Bayumi, the cinematographer of In the Land of Tutankhamun, was the director of the G.C.C.'s Alexandria branch. ${ }^{57}$

The received narrative of Layla as a nationalist triumph has become so entrenched that, having cited evidence to the contrary, a contemporary critic sees no contradiction in asserting that "the film Layla by 'Aziza Amir marks the real beginning of the long, silent Egyptian film, because those who participated in itfrom acting to production-are Egyptian through and through." ${ }^{8}$ The production of Layla-not unlike that of In the Land of Tutankhamun-could, conversely, be held up as a testament to the diversity of the performing arts in Egypt, and to the foreign and minority involvement in the film industry during this era. Vedat (Wedad) Örfi, a Turkish actor, writer, and cinematographer, was originally contracted to direct the film. Although Amir removed him from his role as director partway through production, Örfi continued to act in the film. One of the other actors in the production, Stefan Rosti, replaced Örfi as director. Rosti's mother was an Egyptian resident with Italian nationality, and his absentee father was Austrian. As Dickinson writes: Layla itself, like no film prior to it, "enacted these formations of urban multiculturalism without, however, undermining Egypt." ${ }_{59}$ Although Amir's production involved cinema professionals from a range of nationalities, "she managed to forge from their interaction something that fitted snugly into the proud new standards of Egyptianness circulating in the $1920{ }^{\prime \prime}{ }^{60}$ Dickinson makes clear that the lines critics have historically used to determine what makes a film "Egyptian" are arbitrarily drawn and unevenly applied.

For both historical and theoretical reasons, the nationality of participants is a problematic criterion for determining the national character of a film. Between 1923 and 1940, a total of one hundred seventeen feature films were produced in Egypt. According to one accounting, only five of those films were produced by a cast and crew comprising exclusively Egyptian nationals, the first of which was the 1933 film Al-Khatib raqam 13 (The Thirteenth Fiancé), directed by Muhammad Bayumi. ${ }^{61}$ In other words, strict adherence to the criterion of nationality would produce a truncated and distorted narrative of Egyptian cinema history.

\section{NATIONAL CINEMA WITHOUT NATIONALITY}

In my analysis of Egyptian national cinema, I take as my point of departure the assumption that the notions of nation and nationality are themselves unstable constructs. The writings of Ernest Gellner, Benedict Anderson, and Homi Bhabhaand the subsequent contributions of a generation of scholars-have argued for the 
constructedness and indeterminacy of the nation. ${ }^{62}$ Further, as Mette Hjort and Scott MacKenzie assert, films do not "simply represent or express the stable features of a national culture"; rather, films "are themselves one of the loci of debates about a nation's governing principles, goals, heritage and history." Hjort and MacKenzie advocate that critics "be attuned to . . . what these films and their categorization as elements of a national cinema may elide or strategically repress." ${ }_{3}$

There are, needless to say, ways to delineate the boundaries of national cinema that do not rely upon the spurious practice of ascertaining the nationalities of everyone involved in a production. Paul Willemen considers two primary factors in delimiting national cinemas: address, and national specificity. ${ }^{64}$ For Willemen, "address" refers to presumed audience, recognizing the ways cinema is transnational both in its influences and in its consumption. ${ }^{65}$ National specificity is, in his view, "a territorial-institutional matter" that "designates cultural practices and industries on the terrain governed by the writ of a particular state." 66 In other words: "[T]he boundaries of cultural specificity in cinema are established by governmental actions implemented through institutions" - such as economic barriers and incentives, licensing regulations, and censorship laws. ${ }^{67}$

In what follows I outline some of the institutions that provide the framework within which films were produced in 1930s Egypt. A discussion of these institutions and industry-wide efforts to overcome structural barriers can provide us with an alternative way to think of cinema production in Egypt as a national cinema. Further, during the early years, cinema production in Egypt was seen as contributing to a nationalist agenda. In Egypt, cinema professionals of all nationalities, including Mizrahi, participated in a collective effort to launch an industry they deemed to be of national importance. This patriotic spirit extended to both artistic and commercial aspects of cinema production.

\section{Cinema Practices and National Cinema}

Cinema houses were both the locus of "address" - the site where audiences viewed films - and an institution against and through which the Egyptian cinema industry coalesced. The interests of cinema owners often conflicted with those of Egyptian filmmakers and Arabic-speaking audiences in the early years of local cinema production. For example, although the production of the film Layla was heralded with much fanfare by the Egyptian press, when producer and star 'Aziza Amir sought a screening venue, she met resistance. The interests of cinema owners were, in the early years, at odds with those of the Arabic-speaking Egyptian cinemagoers, and with those of the founders of the nascent Egyptian cinema industry. Cinema owners, many of whom were noncitizen residents of Egypt, were initially dubious that Egyptian films could meet the profit levels of imported films. In order to strike a deal for a weeklong run at Cinema Metropole, Amir had to agree to turn over 30 percent of the proceeds and guarantee the cinema a minimum profit for the 
week of 400 Egyptian pounds. ${ }^{68}$ Layla was ultimately a commercial success. Premiering on 16 November 1927, Layla ran for a week, as was common at the time for first-run features. The film earned three times what it cost to produce. ${ }^{69}$

The success of Layla in 1927 convinced Egyptian financier Muhammad Tal'at Harb to shift the attention of his film-production outfit, Sharikat Misr li-l-tamthil wa-l-sinima (Misr Company for Acting and Cinema), from newsreels to feature films..$^{70}$ In January 1934, the umbrella Misr Group announced its plans to establish a state-of-the-art studio on Pyramids Road in Giza. Studio Misr, as it was called, intended to launch its own productions and accommodate needs of other domestic film producers, from soundstages to lab services..$^{71}$ Ground was broken in March 1934, and the studio was inaugurated in October 1935. The Egyptian media eagerly followed developments at Studio Misr. The weekly journal Al-Ithnayn, which launched three months after construction was begun on Studio Misr, regularly reported on the studio's activities-from personnel changes to gossip about new productions.

Cinema practices helped to galvanize the industry and shape the rhetoric of filmmakers, producers, and critics in other ways as well. With the advent of sound, foreign-language films presented an even greater barrier to Arabicspeaking Egyptian audiences than silent film had. Cinemas commonly projected Arabic translations onto a second screen. While films projected this way served the interests of Hollywood executives and local distributors, ${ }^{72}$ Egyptian viewers, and the local press, began agitating for subtitles to be projected directly on the large screen. ${ }^{73}$

In 1933, the Group of Cinema Critics (G.C.C.) took an activist approach to making cinemas more welcoming to Arabic-speaking Egyptian audiences. They issued a series of directives for cinema owners:

1. The Arabic language should always be part of the introduction-in the program and in the films.

2. Arabic translation should be accurate and in proper style.

3. It is the Egyptians' country; treat them with respect.

And they concluded with the admonishment "Remember this well, Cinema owners. From now on we will not forgive you." ${ }^{74}$

In the fall of 1933, coinciding with the publication of the G.C.C.'s directives to cinema owners, as well as with a student-led movement to boycott foreign-owned cinemas, ${ }^{75}$ the American Cosmograph theaters in both Alexandria and Cairo were purchased by an Egyptian company, Egyptian Cinematograph Company, under the direction of 'Abd Allah Abaza. From the beginning, the management signaled its interest in serving an Arabic-speaking audience. The opening party at the Cairo cinema once called American Cosmograph but later renamed Cinema Fu'ad, featured a performance by Umm Kulthum, and the theater sought, unsuccessfully, 
to book the recently released Egyptian film Al-Warda al-bayda' (The White Rose, Muhammad Karim, 1933), starring Muhammad 'Abd al-Wahab. ${ }^{76}$ The American Cosmograph in Alexandria, however, having been denied screening rights to The White Rose, instead paired its screening of a Hollywood feature with a short film by Yusuf Wahbi and a sketch by Badi'a Masabni. ${ }^{77}$ The following year, Cinema Fu'ad in Cairo was rented out by Josy Films, a company owned by the Jewish-Egyptian Mosseri brothers that distributed films and operated a number of theaters. ${ }^{7}$ Under the management of Josy Films, the Cairo theater reverted to the name American Cosmograph, and the cinemas remained committed to screening locally produced films-both "Egyptian" and "mutamassir."79 The term mutamassir" (pl., mutamassirun) refers to a subset of the noncitizen residents who, like Mizrahi, integrated into Egyptian society. Throughout his career, most of Mizrahi's films premiered at both American Cosmograph theaters.

Through the 1930 and early 1940 s filmmakers and critics-along with the owners of Egyptian-oriented cinemas like Cinema Fu'ad / American Cosmographsought to make locally produced cinema available to the urban, Arabic-speaking populace. Further, the Egyptian film industry of this era-production, distribution, and criticism - shared a national spirit, and promoted the view that a robust local cinema industry was in the national interest. This phenomenon was not unique to Egypt. As Andrew Flibbert demonstrates, in emerging film markets outside of the United States and Europe, "[s] ound added a dimension to the medium that nationalist filmmakers could deploy to promote national identities."

\section{Nationalism and National Cinema}

Egyptian cinema developed in the context of the Egyptian independence struggle. Although still nominally an Ottoman province, British troops occupied Egypt in 1882, and Egypt remained under British dominance until the middle of the twentieth century. Following World War I, Egyptians took to the streets demanding independence, launching the 1919 Revolution. Egypt was granted limited independence in 1922, but British troops remained in Egypt. The Anglo-Egyptian treaty of 1936 pledged withdrawal of British troops and granted Egypt greater autonomy in the conduct of international affairs. But until the 1952 Free Officers revolt, Egypt remained under British influence, and British troops remained in the Suez Canal zone until 1956.

The 1919 revolution brought about the rise of adab qawmi (national literature). Literature and the arts echoed the pervasive national spirit. The emerging cinema industry, too, contributed to this "cultural call for national art and literature." ${ }^{{ }_{11}}$ In this vein, in a treatise on cinema published in 1936, filmmaker Ahmad Badr Khan laid out guidelines for cinema practices that reflect "the Egyptian spirit." ${ }^{2}$ Egyptian film critics, too, championed the emerging industry as a source of national pride. In 1933, the G.C.C. proclaimed: "We are supporters of Egyptian cinema. Its 
success is our success. With its rise we raise our heads high." ${ }^{83}$ Political figures also endorsed cinema as contributing to the nationalist cause. Upon the release of the musical The White Rose (1933), filmmaker Muhammad Karim received notes from political figures active in the Wafd Party congratulating him on contributing the nationalist cause: Safiya Zaghlul called it a "nationalistic and futuristic project," while Mustafa al-Nahhas deemed it a "patriotic film." ${ }^{4}$ In the 1930s, the production of local cinema in Egypt was widely embraced as a national cause.

The establishment of Studio Misr in 1934 is widely lauded as "the proper foundation of the Egyptian film industry" ${ }^{5}$ Yet, Studio Misr never achieved the desired vertical integration from production to distribution to exhibition that characterized the Hollywood model, even after purchasing a cinema in $1938 .{ }^{86}$ Nor did Studio Misr achieve industry dominance in Egypt. Instead, in Viola Shafik's words, it "functioned as a catalyst for the rest of Egyptian cinema, as it set new technical and artistic standards" ${ }^{87}$ for the robust growth of the local cinema industry. Nevertheless, the Misr Group, which owned Studio Misr, was adept at securing its wideranging business interests in the Egyptian economy. It also promoted its image as a force in the Egyptian struggle for economic and political independence. ${ }^{88}$

Studio Misr was not alone in its promotion of what Ifdal Elsaket calls "economic nationalism." ${ }^{\prime 9}$ Like other Egyptian capitalists at the time, cinema producers saw the growth of local industry as "protecting Egypt from foreign domination." Echoing the calls in other sectors of the economy for import-substitution industries, critics and cinema producers alike viewed the film industry as contributing to the Egyptian fight for economic independence. ${ }^{91}$ Until the mid-1940s, the Egyptian government placed few restrictions on the import of foreign films. Tariffs were relatively low, and there were no screen quotas..$^{92}$ Over the course of the 1930s, independent studios-which otherwise saw themselves as competitorsattempted to band together to promote state intervention and economic protection of the fledgling industry.

Beginning in early 1936, there were a series of industry-wide efforts to promote the development of Egyptian cinema. In January 1936, industry professionals and highly respected cultural figures, including 'Aziza Amir and Huda Sha'arawi, gathered to discuss ways to collectively support the production of Egyptian cinema. In the opening remarks to the conference, 'Abd al-Rahman Rida characterized the growth of the Egyptian film industry as "a duty" for the benefit of Egypt and the Arab world. He elaborated:

We cannot live in a world dependent upon what comes to us from the West. We should not be satisfied with it. Regardless of the quality or beauty of the cinema production of the West, thousands or millions of Egyptians and people in the Arab world cannot benefit from Western films because of the difference in language and our audience's inability to understand the dialogue..$^{93}$ 
While some speakers extolled the virtues of cinema as an art form, the resolutions passed at the conference focused on cinema as a local industry that required government protection. ${ }^{94}$ In particular, the conference sought to exempt local studios from duties on imported cinematic equipment and reduce the amusement tax imposed on locally produced films. ${ }^{95}$

In May 1936, the Union of Egyptian Cinema was formed to promote a platform that echoed the resolutions of the conference, and to elicit guarantees from cinema owners to screen Egyptian films. Ahmad Salim, director of Studio Misr, was elected president, and Togo Mizrahi was elected secretary.$^{96}$ In the weeks before the convening of the second cinema conference in January 1937, the union splintered. Salim, immersed in the business of running Studio Misr, failed to defend the work of his colleagues against an attack in the press. In response, independent film producers broke off to form their own organization under the leadership of Isma' il Wahbi, Mahmud Hamdi, and Ahmad Galal. ${ }^{97}$ Despite the rift, these cinema producers and directors uniformly viewed themselves as promoting a vital national industry and engaging in a cultural project of national importance.

Held in 1937, the second cinema conference explicitly reflected state interests in the growth of cinema. The formal statement issued by the organizing committee unambiguously adopts nationalist rhetoric: "Our goal is for Egypt to become independent: economically, nationally, and cinematically. We hereby pledge to exert all efforts until the Egypt cinema industry becomes completely independent."98 The conference focused on three aspects of cinema production: artistry, social impact, and financial concerns. The financial considerations were tied closely to the broader goal of "bolstering the national economy" and "achieving economic independence."99

\section{Industry Boosterism versus Nationalism}

In the 1930s, Egyptian filmmakers, who saw themselves as engaging in an art and industry of national importance, regularly employed patriotic rhetoric to promote their efforts. The press would sometimes take issue with industry practices and call out empty gestures made in the name of national pride. For example, a 1934 editorial that appeared in Fann al-sinima, the organ of the G.C.C., took a dim view of the quality of Egyptian film production, dismissing Egyptian films as underfinanced vanity projects, motivated by petty competition. In the view of the critic, audiences flocked to see these "weak individual efforts" driven by a misguided sense of national pride. The editorial satirically sums up the process of Egyptian film production in the early 1930s as follows: "When someone gathers the resources to produce a film, he forms his own company under his own name, and then seeks a subject, whether it be substantial or weak, and produces a film.... The camera rolls, there is acting and shooting, and the whole farce is projected on the silver screen." ${ }^{100}$ Consistent with Tal'at Harb's announcement the previous 
month of the Misr Group's plan to build a state-of-the-art studio, the article concludes that the future of the film industry lay in raising greater capital to produce higher-quality films. ${ }^{101}$ As the article makes clear, the empty rhetoric of national pride is not sufficient to fuel a successful industry.

Indeed, marketing films on the basis of patriotic sentiment led to some headscratching associations. Take, for example, an early effort to dub a film into Arabic: Beyond Bengal (1934, Harry Schenck). Dubbing held some promise for making foreign sound films more widely available to the Egyptian viewing public, but it was more expensive than projecting translated titles.

After viewing Beyond Bengal, a wildlife film shot on location in the Malay Peninsula, two Egyptian cinema professionals-the actor Sarag Munir and the cinema editor for the daily newspaper Al-Ahram, Zakariya Sharbini-decided to underwrite dubbing the film into Arabic. They cited the film's educational value as a motivation for making this "rare glimpse at life in the jungle" widely available to the Egyptian viewing public. ${ }^{102}$ Only sixty-five minutes long, the film was shot silent and featured voice-over narration, making it, technically speaking, a good choice to experiment with the dubbing process. ${ }^{103}$

The Arabic version premiered in February 1936 under the title Sadat al-adghal (Masters of the Jungle). The promotion of Beyond Bengal / Masters of the Jungle in Egypt played on familiar nationalist tropes. The release of "the first foreign film made into an Arabic-speaking film," an ad in Al-Sabah proclaims, serves "the interest of Egyptianizing cinema"104 Cinema al-Nahda, an Egyptian-owned cinema, vaunted its identification with the nationalist cause by adopting a tagline that paraphrased a popular slogan of the 1919 Revolution: "Egypt for Egyptians." Cinema al-Nahda advertised itself as projecting "cinema created by Egyptians for Egyptians." 105

But rather than reflecting the pluralist, anticolonial nationalist spirit of 1919, Beyond Bengal draws upon the very racist tropes used to justify European colonialism. ${ }^{106}$ The film further offers words of praise for the sultan of Perak, who supported the expedition. The sultan appears briefly on-screen, accompanied by a British officer, Captain Lindsay Vears. At the time, Perak was part of the Federated Malay States, a nominally independent British protectorate, much like Egypt. ${ }^{107}$

The Egyptian advertisement for the dubbed version of Beyond Bengal / Masters of the Jungle casts the technical achievement as a nationalist endeavor, evoking a slogan of the 1919 Revolution. Yet this rhetoric is employed in the service of an Orientalist, pro-British, royalist adventure-travel docudrama. How do we square the film's politics with the nationalist, anticolonial rhetoric evoked in the ad? Industry boosterism, even when cloaked in a rhetoric of national pride, is not the same as nationalist cinema.

Despite such examples of overreach, Egyptian filmmakers of the 1930s genuinely saw themselves as engaging in a nationalist endeavor. The content of Egyptian 
cinema in the 1930 and 1940 s was not "nationalist" per se. To be sure, the industry steered clear of direct political interventions and topics that might run afoul of state censors. ${ }^{108}$ The late 1930 s saw two high-profile projects censored as a result of perceived political content. ${ }^{109}$ Some historical films, such as Shagarat al-Durr (1935), directed by Ahmad Galal, and Salah al-Din (1941), directed by Ibrahim Lama, have been read as political allegory. ${ }^{110}$ But the bulk of films produced were musical melodramas or comedies. Some films were set in the "legendary past," and featured lavish sets and costumes. ${ }^{111}$ Thus, while some Egyptian films produced in the 1930s-like those of Togo Mizrahi-could be described as socially conscious, as a whole, they were not overtly political.

The anticolonial, nationalist lens that dominates Egyptian cultural criticism following the 1952 Free Officers revolt disparaged early cinema efforts, obscuring the nationalist agenda that filmmakers embraced and that the press and audience recognized and celebrated. ${ }^{112}$ According to Walter Armbrust, until the 1990 os there was widespread critical consensus that "there is little value in most of the films made [in Egypt] in the three decades before the 1960s." ${ }^{113}$ Looking back, later critics criticized what they saw as the Orientalist aesthetic in silent cinema-attributable, in their view, to the role of foreigners in establishing the film industry. Evaluating the commercial genre films of the 1930 s and 1940 s by content rather than their nationalist promotional rhetoric, critics denigrated them as derivative of Hollywood and reflective of decadent, bourgeois values. During World War II, fewer foreign films were distributed, providing an opening in the market. In the years after the war, local capitalists, enriched by the war effort, began to view cinema as a worthwhile investment. ${ }^{114}$ Film production rose substantially. ${ }^{115}$ As a result of this dynamic, Egyptian critics and film historians cast aspersions on films produced between 1945 and 1952 as a "cinema of war profiteers."

Post-Nasser nationalist histories of Egyptian cinema find two positive developments in the 1930s that set the stage for the development of "serious" cinema: the establishment of Studio Misr, and the rise of social realism. The narrative of Studio Misr as Egypt's first modern studio has survived in a way that is consistent with the perception of the Misr Group as a whole. As Robert Vitalis demonstrates, the Misr Group achieved economic dominance through a variety of capitalist endeavors in the 1940 s in a way that secured its position in postrevolutionary anticolonial Egypt. Yet it also managed to control the public's perception of the company as a supporter of Nasser's anticapitalist etatism. ${ }^{116}$

In the 1950s, the idiom of social realism rose to prominence in Egyptian cinema. The genre of melodrama emerged as the vehicle for narrating the national liberation struggle and articulating the postcolonial national imaginary. ${ }^{117}$ Later critics widely lauded the 1939 melodrama Al-Azima (Determination, Kamal Salim) as the first "sign of maturity of cinema art in Egypt," ${ }_{118}$ in part because of the way it conforms to the political agenda and generic preferences of Nasser-era filmmaking. ${ }^{119}$ In a 1996 survey of Egyptian cinema industry professionals, Determination 
was voted the best film ever produced in Egypt. Not a single other film produced in the 1930 made the top-100 list. ${ }^{120}$

\section{TOGO MIZRAHI: A CASE STUDY OF NATIONAL CINEMA WITHOUT NATIONALITY}

This book, Togo Mizrahi and the Making of Egyptian Cinema, starts from the position that there is indeed a great deal to be learned from examining Egyptian cinema production of the 1930 and 1940s. I have chosen to focus my analysis on the work of a single director and producer. A close examination of Mizrahi's career serves to complicate the focus on nationality that commonly delimits the boundaries of Egyptian cinema. Like Victor Rosito, the director of In the Land of Tutankhamun, Mizrahi was an Italian national. Like Stefan Rosti, the director of Layla, Mizrahi was mutamassir, an acculturated Egyptian, who contributed to local cultural production. Togo Mizrahi was also a Jew.

Like other Egyptian filmmakers in the 1930s and 1940s, Mizrahi avowedly subscribed to the view that developing a local cinema industry was a nationalist project. In 1929, Mizrahi chose to name his newly founded production company Sharikat al-aflam al-misriyya, the Egyptian Films Company. Promotional materials for Mizrahi's films tapped into the audience's desire to see locally produced cinema. For example, an advertisement touted Al-Bahhar (The Sailor, 1935) as a film of "the Egyptian popular classes," one that showed "the true face of Egypt." ${ }^{121}$ After relocating his studio from Alexandria to Cairo in 1939, Mizrahi often included a logo in his films that prominently featured a crest bearing a crescent and three stars, the symbol of the Kingdom of Egypt. A later modification of the company's logo visually integrated cinema and nationalist sentiment: a length of film spooling out from the words "Sharikat al-aflam al-misriyya," winding three times around the crest (fig. 3).

During his career, Mizrahi actively participated in the collective efforts by industry professionals to agitate for state protection of the Egyptian film industry, serving as secretary of the Union of Egyptian Cinema beginning in $1936 .{ }^{122}$ The Alexandria branch of the organization, directed by Edmond Nahas, was located in the offices of Studio Mizrahi. ${ }^{123}$ Mizrahi also defended the economic viability of the Egyptian film industry in the press. ${ }^{124}$

In October 1936, Mizrahi threw a party at his Alexandria studio that he billed as a celebration of "the signing of the treaty of Egyptian independence." While Egypt had been granted nominal independence in 1922, Great Britain continued to occupy Egypt. The Anglo-Egyptian treaty, signed in August 1936, laid out the framework for Great Britain to withdraw its troops from Egypt. In attendance were a number of luminaries of the Alexandria cinema industry, including cinema owners, and cinema union director Edmond Nahas. 


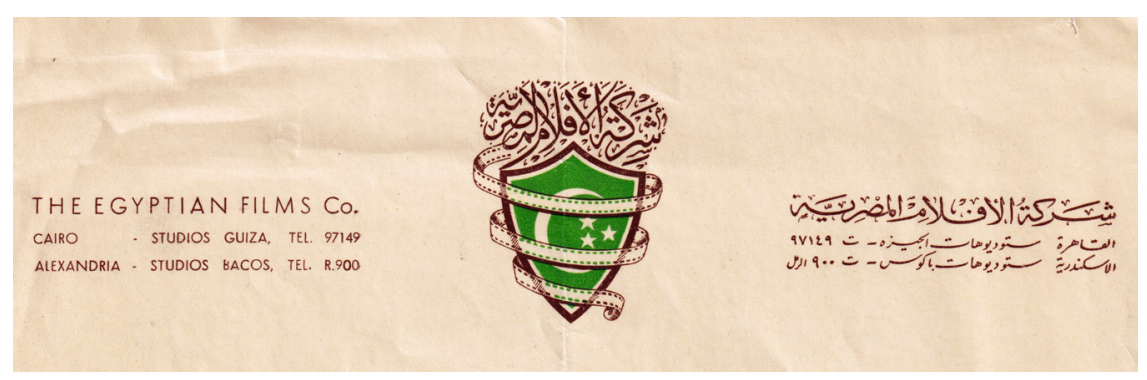

FIGURE 3. Letterhead for the Egyptian Films Company featuring the company logo. Courtesy of Jacques Mizart.

Mizrahi addressed the crowd, congratulating the Egyptian delegation on its success. He wished Egypt prosperity in the future, and offered his good wishes to the recently installed monarch, King Farouk. Actor Hasan Salih, who was featured in Mizrahi's film Khafir al-darak (The Neighborhood Watchman), to be released later that month, performed several monologues for the guests, including one written in honor of the treaty. ${ }^{125}$

Contemporaneous critics praised Mizrahi for the quality of his films and his contribution to building the Egyptian cinema industry. One 1937 article proclaimed: "No one can deny Mr. Mizrahi's contributions to the world of cinema, nor the rapid steps he has taken toward the advancement of filmmaking in Egypt. It is not an exaggeration to say that such efforts paved his way to making excellent films that were well received by the audience. This reception is well deserved due to the films' high quality." ${ }^{126}$

By contrast, in the years following the 1952 Free Officers revolt, nationalist critics tended to marginalize Mizrahi's contributions to Egyptian film history. Critics have found ways to acknowledge Mizrahi's contributions to Egyptian cinema, but also to downplay them. In 1967, for example, Samir Farid simultaneously inscribes and erases Mizrahi's contributions to the development of Egyptian cinema. Farid, an influential and prolific film critic, describes the history of Egyptian cinema as reflecting the politics and aesthetics of two distinct schools: "We can divide into two categories the schools of directing in Egyptian cinema: the first is the Alexandria school, of which Togo Mizrahi was one of the founders; and the second is the Cairo School, to which most of the directors belong, like Muhammad Karim and Ahmad Badr Khan, Kamal Salim and Salah Abu Sayf." ${ }^{127}$ While he identifies Mizrahi as leading a school of Egyptian cinema production, Farid dismisses Mizrahi's filmmaking as irrelevant to Egyptian film history. Anyone with any familiarity with Egyptian cinema history would understand that for Farid, Mizrahi's Alexandria school represents a dead end-Egyptian cinema issued from what Farid calls "the Cairo School." 
In recent years, proponents of "cosmopolitan Alexandria" narratives have attempted to recuperate the contributions of foreign and minority industry professionals like Togo Mizrahi. Film critics and historians have also documented the Alexandrian origins of early cinema in Egypt, providing a significant counternarrative to the Cairo-centric view that locates the real start of Egyptian cinema with the establishment of Studio Misr in 1934. For example, in Madrasat al-Iskandariyya li-l-taswir al-sinima'i (The Alexandria Cinematographic School), Ibrahim Dasuqi and Sami Hilmi revisit Samir Farid's distinction with the intent of restoring the image of "the Alexandria school." They elaborate upon Farid's categorization as follows: "Alexandria: the sea and open vistas; cosmopolitanism. In cinematic language: shot on location; coexistence between the races and religions. Cairo: city surrounded by dusty hills closed in on itself. In cinematic language: shot on sets; an expression, essentially, of the Egyptian middle class." ${ }_{128}$

The Alexandria Cinematographic School was published by the Bibliotheca Alexandrina, as part of an effort to document the city's cinematic history and the "pioneering role that foreigners played." 129 Sahar Hamouda and Muhammad Awad, who edit the Bibliotheca Alexandrina series, write:

There was a synergy between the open city that encouraged innovation, entrepreneurship and modernism, and its people who were a healthy mix of foreigners recently arrived at the port or who had been in Alexandria for a few generations, and Egyptians arriving from Cairo or who had been in Alexandria for a few generations. Such a synergy - the product of a certain time and place-was the reason why Alexandria was a pioneer in many areas, not just the cinema industry, and it was in inspiration and innovation that Alexandria excelled. ${ }^{130}$

Mizrahi epitomizes the cosmopolitan ethos they map-and he plays a central role in the narrative they reconstruct about the importance of Alexandria in the development of cinema in Egypt. Mizrahi, an Alexandrian Jew, directed and produced popular Arabic movies, as well as the first Greek-language films in Egyptian history.

Togo Mizrahi's oeuvre properly belongs to both narratives of Egyptian cinema-the Cairo-centric nationalist narrative and the Alexandria-centric cosmopolitan narrative. This book analyzes how Mizrahi's films articulate both a pluralist nationalism and a locally situated cosmopolitanism.

Building on critical constructions of the notion of national cinema, I seek to situate Mizrahi's films-with their distinctly pluralist vision-within the arc of Egyptian cinema development in the 1930s and 1940s. As Susan Hayward writes: "A national cinema can problematize a nation by exposing its masquerade of unity." ${ }^{131}$ Hayward calls for a framing of national cinemas that "perceives cinema as a practice that should not conceal structures of power and knowledge but which should function as a mise-en-scène of scattered and dissembling identities as well as fractured subjectivities and fragmented hegemonies." ${ }^{132}$ In Togo 
Mizrahi and the Making of Egyptian Cinema, I seek to contribute to constructing a narrative of Egyptian cinema history in terms of this flexible notion of "national cinema" - a cinema of "national specificity" (Willemen) that "problematizes the nation" (Hayward). ${ }^{133}$ Such a construction of the national stands in opposition to "nationalist cinema" characterized by Willemen as "complicit with nationalism's homogenizing project." ${ }^{134}$

The Egyptian cinema industry of the 1930s-a diverse mix of Egyptians, mutamassirun, and foreigners-saw itself contributing to a national project. It should come as no surprise that the Egypt reflected in these films mirrored this flexible, inclusive notion of national belonging. Togo Mizrahi's films are emblematic of this phenomenon, but he is not alone. Other films produced in this era-including some produced by Studio Misr and by Assia Dagher's Lotus Films-also expose, in Hayward's terms, the nation's "masquerade of unity." ${ }^{35}$

In my reading of 1930s Egyptian cinema, I adopt the term "Levantine" to critically engage with this cinematic pluralist nationalism. The term "Levantine" has been used to describe an urban diversity of cultures, like the Egyptian urban society that Mizrahi portrays on-screen, and in which he produced his films. The term also refers to residents of the Levant, particularly in contexts in which an observer cannot readily discern the ethno-national or religious identity of the observed. I employ the notion of the "Levantine" to explore the potential of this indeterminacy, and the inherent performativity of crossing between and among cultures, languages, and communal groups ${ }^{136}$

The way I am using the term "Levantine" is distinct from the term "cosmopolitan." As I argued in Remembering Cosmopolitan Egypt, the notion of the cosmopolitan is inextricable from empire. ${ }^{137}$ As a philosophical construct, the cosmopolitan emerges out of imperial contexts. ${ }^{138}$ With regard to Egypt, the term "cosmopolitan" is often used to refer to an ethno-religiously diverse class of immigrants, foreigners, and minorities in Egypt during a period not coincidentally coterminous with the European colonial enterprise in Egypt. Further, it is most commonly applied to members of the bourgeoisie who by and large did not hold Egyptian citizenship and did not identify with Egyptian culture: most spoke languages other than Arabic; most saw themselves as European. ${ }^{139}$

By contrast, the Levantines portrayed on-screen in the films discussed in this book (like those involved in their production) represent a variety of religions and nationalities. Most of the Levantine characters in these films speak Egyptian Arabic: they are portrayed as part of the fabric of Egyptian society. The multiculturalism, syncretism, and cultural exchange represented by these Levantine films are most evident among residents of lower-class urban neighborhoods. While the term "cosmopolitan" is elitist and distinctly European, the Levantine is not classspecific and is firmly situated in the region. ${ }^{140}$ The term "Levantine" highlights both the diversity of Mizrahi's Egypt and the performativity of identity reflected in his films. 
In my readings of 1930 Egyptian cinema, I have identified three common characteristics of what I term a "Levantine cinematic idiom." First, Levantine films reflect and engage with an ethics of coexistence. Second, they utilize cinematic tools to construct a pluralist aesthetic. Finally, in true Levantine fashion, these films foreground the performativity of identity. I am particularly attuned to ways masquerade is employed in these films to subvert hegemonic or homogenizing notions of identity.

In chapter 2, I provide an integrated analysis of Togo Mizrahi's biography and filmography. I examine Mizrahi's personal narrative in the context of modern Egyptian Jewish history. I situate his films and their reception within the context of Egyptian cinema history. Tracing the arc of his career, I outline the development of Mizrahi's commitment to producing socially conscious films, and track issues that recur throughout his oeuvre.

In chapters 3 through 7, I read a selection of Mizrahi's films to unpack the ways they employ this Levantine cinematic idiom to construct a pluralist nationalism and a locally situated cosmopolitanism. Through close analysis of Togo Mizrahi's films, I tease out the cultural and political implications of his oeuvre, with particular attention to the construction of pluralist nationalism, the representation of Jewishness, and the disruptive deployment of unstable gender categories.

Chapter 3, "Crimes of Mistaken Identity," establishes how two of Mizrahi's early films utilize liminal characters (the poor, minorities) to define the boundaries of law and nation. I analyze two comedies of mistaken identity in which Levantine pairs-a Jew and Muslim in Al-Manduban (The Two Delegates, 1934), and a Nubian and a Lebanese in Khafir al-darak (The Neighborhood Watchman, 1936)-thwart sinister plots of an international crime syndicate. ${ }^{141}$ In these films, Levantines subvert social codes and notions of national belonging, but they are also depicted as civic-minded and law-abiding subjects who work for the common good.

With their focus on the plight of the urban lower classes, Mizrahi's films articulate the form of national belonging popularly known in Egypt as "ibn al-balad." As already noted, Mizrahi titled his first sound film Awlad Misr (Children of Egypt) to echo the plural form of this expression: awlad al-balad. Several of Mizrahi's films, I argue, seek to broaden the category of ibn al-balad. The construct is usually applied only to Muslims. In chapter 3, I unpack how in The Two Delegates Mizrahi expands the notion of "ibn al-balad" to include Jews, as a means of asserting arabophone, Egyptian-Jewish nativeness.

In chapter 4, "Queering the Levantine," I examine Mizrahi's Al-Duktur Farhat (Doctor Farahat, 1935) 142 and Mistreated by Affluence (1937). I argue that these films, through their narratives of mistaken identity, queer both ethno-religious identities and gender. For example, Mistreated by Affluence opens with Chalom, a Jew, and 'Abdu, a Muslim, waking up together in a shared bed. Starting with this image, I analyze the interrelationship between an ethics of coexistence and destabilized, performative gender identities. 
Building on this discussion of Levantine queerness, chapter 5, "Journeys of Assumed Identity," examines how Levantine mobility of identity and physical mobility inform one another. In this chapter, I unpack the journeys of assumed identity in Mizrahi's Al-sa'a 7 (Seven O'Clock, 1937), featuring 'Ali al-Kassar in his signature role as 'Usman 'Abd al-Basit. These journeys serve to explore the boundaries of both nation and identity. The film's three acts depict three distinct itineraries. In the first movement, circular trajectories encompass Alexandria's diversity, in a Levantine ethics of inclusion. In the second movement, the urban migrant's ambivalent return to his native home, Aswan, serves to mark the boundaries of nation. This itinerary also explores racial and cultural variation within that nation. In the third movement-toward Cairo-'Usman masquerades as a Nubian woman, revisiting the queer Levantine idiom explored in the previous chapter.

In the first thirty years of Egyptian sound film production, more than a third of all films produced were musicals. ${ }^{143}$ Mizrahi's films produced between 1930 and 1939 in his Alexandria studio feature episodic plots that often contain a song or two. With the move to Cairo in 1939, Mizrahi expands his cinematic idiom to include musicals. Mizrahi's first film produced in Cairo, Layla mumtira (A Rainy Night, 1939), featured Egyptian Jewish singer Layla Murad, who had already received critical acclaim for her performance opposite Muhammad 'Abd alWahab in Yahya al-hubb (Long Live Love, Muhammad Karim, 1938). In chapters 6 and 7, I examine how Mizrahi's musical melodramas continue to examine both the boundaries of the nation and the boundaries of gender.

Chapter 6, "Traveling Anxieties," argues that itineraries traveled in Mizrahi's musical melodramas-like in his earlier comedies-explore the limits of the Egyptian nation and national identity. In this chapter I discuss the films A Rainy Night (1939) and Al-Tariq al-mustaqim (The Straight Road, 1943). Although these films do not have any explicitly Jewish content, I argue that that they reflect distinctly Jewish anxieties. The itinerary in A Rainy Night, from Milan to Cairo to Omdurman, counterposes rising fascism in Europe with Egypt's Levantine and multiracial society. The itinerary also raises questions about the boundaries of the nation elicited by Egypt's colonial designs on Sudan, even as British troops continue to occupy Egypt. In The Straight Road, a character en route from Cairo to Beirut drives his car off a cliff along the Palestinian coast; presumed dead, he loses his identity. I tease out how this itinerary reveals Egyptian Jewish anxieties about the impact of Zionist efforts in Palestine on their future in Egypt.

Chapter 7, "Courtesan and Concubine," analyzes the performance of female sexuality and the sexuality of performance in musical melodramas that feature two of the biggest female stars in 1940s Egypt. Layla (1942), an adaptation of Alexander Dumas fils's novel La dame aux camélias (1848), stars Layla Murad in the role of a courtesan. Sallama (1945), an adaptation of 'Ali Ahmad Ba Kathir's novel Sallamat al-qass (1941), stars Umm Kulthum in the role of a qayna, a singing slave girl. I 
analyze these films in the context of contemporaneous transformations of women's roles in Egyptian society and efforts to abolish legal prostitution in Egypt.

In 1946, Togo Mizrahi abruptly withdrew from cinema production. In 1952, he settled permanently in Rome, where he lived until his death in 1986. In the concluding chapter, "Frames of Influence," I assess the lasting impact of Mizrahi's films. Long after Mizrahi's withdrawal from cinema production in 1946, his films continued to be available to the viewing public. Mizrahi's films aired on Egyptian and Israeli television, then screened on satellite networks, and currently stream on YouTube. I identify a series of cinematic moments that serve to articulate Mizrahi's influence in Egyptian cinema and beyond. I also explore how Mizrahi figures in Egyptian-Jewish diaspora culture in both Israel and France.

Togo Mizrahi's films assert his identity as "son of Egypt." Combining film analysis with archival research in contemporaneous journals and newspapers, Togo Mizrahi and the Making of Egyptian Cinema situates this Jewish, noncitizen filmmaker within the nationalist project of establishing Egyptian cinema as both a local art form and a vital domestic industry. 